Available online on 15.03.2021 at http://ujpr.org
Universal Journal of Pharmaceutical Research
An International Peer Reviewed Journal
Open access to Pharmaceutical research
Attribution-Non Commercial Share Alike 4.0 License which permits unrestricted non
commercial use, provided the original work is properly cited
Volume 6, Issue 1, 2021

\title{
BACTERIAL CONJUNCTIVITIS OF ADULTS: CAUSES AND OPHTHALMIC ANTIBIOTIC RESISTANCE PATTERNS FOR THE COMMON BACTERIAL
} ISOLATES

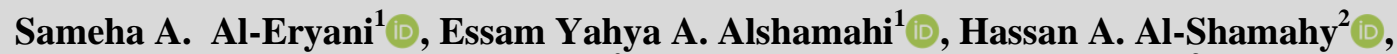
Ghada Hussein A. Alfalahi ${ }^{2}$, Abdulrahman Ahmed Al-Rafiq ${ }^{3}$

${ }^{I}$ Opthalmology Department, Faculty of Medicine and Health Sciences, Sana'a University, Republic of Yemen. ${ }^{2}$ Medical Microbiology and Clinical Immunology Department, Faculty of Medicine and Health Sciences, Sana'a University, Republic of Yemen.

${ }^{3}$ Medicine Department, Faculty of Medicine and Health Sciences, Sana 'a University, Republic of Yemen.

\section{ABSTRACT}

Background: Bacterial conjunctivitis is often observed in newborns as well as in other age groups. It has been associated with several organisms that differed in their relative importance and varied in their response to ophthalmic antibiotics.

Objectives: The aim of this study was to investigate bacterial conjunctivitis of adult patients by determine the specific bacterial causes and determine the ophthalmic antibiotic resistance patterns for the bacterial isolates from conjunctivitis patients in Sana'a city, Yemen.

Methods: Total 521 bacterial swabs obtained from adult patients with suspected bacterial conjunctivitis introducing to the ophthalmology clinics in the tertiary hospitals in Sana'a city, Yemen between September 2016 and October 2017 were investigated for bacteriological agents and antibiotic susceptibility. The clinical samples culturing, and microbiology diagnosis were done at National Center of Public Health laboratories Sana'a (NCPHL).

Result: Total 521 swab results from conjunctiva were performed, of which 206 (39.5\%) were deemed positive for bacterial culture. The isolation rate by bacteria species ranged from $0.5 \%$ to $28.2 \%$. In $S$. aureus isolates, ophthalmic antibiotic resistance varied from $10.5 \%$ for polymyxin B to $66.7 \%$ for erythromycin. In Branhamella catarrahalis isolates, ophthalmic antibiotic resistance ranged from $3.4 \%$ for levofloxacin to $69 \%$ for erythromycin. In Haemophilus influenzae isolates, ophthalmic antibiotic resistance varied from $0.0 \%$ for ciprofloxacin and polymyxin B to $42.1 \%$ for erythromycin and azithromycin.

Conclusion: The most common causative organisms in adult age groups were Branhamella catarrahalis and $S$. aureus. Obviously, there is no single drug that treats these various types of bacteria. Therefore, bacteriological culture and sensitivity in the laboratory to ophthalmic antibiotics should be performed as much as possible. But if laboratory facilities are not available, some generalizations can be made as guidelines for treating conjunctivitis.

Keywords: Adult, bacterial conjunctivitis, causes, ophthalmic antibiotic resistance, Sana'a, Yemen.

Article Info: Received 6 January 2021; Revised 3 February; Accepted 4 March, Available online 15 March 2021

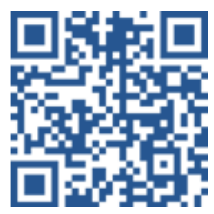

Cite this article-

Al-Eryani SA, Alshamahi EYA, Al-Shamahy HA, Alfalahi GHA, Al-Rafiq AA. Bacterial conjunctivitis of adults: causes and ophthalmic antibiotic resistance patterns for the common bacterial isolates. Universal Journal of Pharmaceutical Research 2021; 6(1):25-28.

DOI: https://doi.org/10.22270/ujpr.v6i1.535

Address for Correspondence

Prof. Hassan A. Al-Shamahy, Faculty of Medicine and Heath Sciences, Sana'a University, P.O. Box 775 Sana'a, Yemen. Tel+967-770299847; E-mail: shmahe@yemen.net.ye

\section{INTRODUCTION}

Conjunctivitis is a group term for a disease variety described by conjunctivitis ${ }^{1}$. Viral infection is the most common cause of infectious conjunctivitis (about $70 \%$ of all cases), followed by bacteria (about $30 \%$ of cases). The non-infectious types are immunogenic, allergic, mechanical/irritant/toxic, and neoplastic are less common than viral and bacterial infections ${ }^{1,2}$.
According to the assessment of the rate of positive culture in adult patients presenting to their general practitioner with red eyes, purulent (mucous) or prickly secretions in the eyelids; It was found that approximately $32 \%$ of them have bacterial causes. It is known that bacterial conjunctivitis is usually unilateral, but it can on occasion involve both eyes ${ }^{3,4,5}$. The most frequent pathogens for bacterial conjunctivitis in adults is staphylococcal species, followed by Haemophilus 
influenza and Streptococcus pneumoniae $e^{6,7}$. In children, bacteria are accountable for $50-75 \%$ of cases of conjunctivitis, which are most often caused by $S$. pneumoniae, Moraxella catarrhalis or Haemophilus influenzae, and the very severe form of bacterial conjunctivitis is caused by either Chlamydia trachomatis or Neisseria gonorrhoeae. Ophthalmologists should delay the use of broadspectrum topical antibiotics as there is no indication to show the advantage of any topical antibiotic agent for its use because methicillin-resistant Staphylococcus aureus conjunctivitis accounts up to $64 \%$ of the causes. This demands management by an ophthalmologist with antibiotics effective against MRSA, such as bisifloxacin ophthalmic suspension ${ }^{1,2,8,9}$. However, inappropriate antimicrobial use is associated with an increase in bacterial resistance, and in recent years a global push has been found to limit antimicrobial prescribing as chloramphenicol has decreased prescribing for conjunctivitis among general practitioners in the United Kingdom but its use has increased several times when it became the first antibiotic available without Prescription $^{3,4}$. The surveillance of causative organisms and patterns of susceptibility is important in guiding antimicrobial selection. While large studies in the $\mathrm{US}^{6,10}$ have investigated trends of bacterial resistance to antimicrobials over the past decade, these studies have limited use in the UK as chloramphenicol, a commonly used antibiotic in the UK, is not used in the states. USA due to rarely alleged association between topically administered chloramphenicol and aplastic anemia.

To our knowledge, this is the first report of this kind from Yemen. The purpose of this study was to investigate adult bacterial conjunctivitis by identified bacterial causes and determine the ophthalmic antibiotic resistance patterns for the bacterial isolates from conjunctivitis patients in Sana'a city, Yemen.

\section{SUBJECTS AND METHODS}

All bacterial swabs collected from adult patients suspected of having bacterial conjunctivitis came to the ophthalmology clinics in the tertiary hospitals in Sana'a city, Yemen between September 2016 and October 2017 were investigated for bacteriological agents and antibiotic susceptibility. The clinical samples culturing, and microbiology diagnosis were done at National Center of Public Health laboratories Sana'a (NCPHL). By using cotton swabs, conjunctival samples were collected from the the inferior conjunctival fornix according to the local protocol. Samples were inoculated on Colombia agar and chocolate agar with $5 \%$ blood and MacConkey agar plates, and then placed in a $5 \% \mathrm{CO}_{2}$ incubator at $37^{\circ} \mathrm{C}$ or in air at $37^{\circ} \mathrm{C}$ for MacConkey agar plate. After 24 and 48 hours of incubation, plates were examined for the presence of pathogens associated with conjunctivitis. The identification of organisms was done by standard laboratory methods. A negative result was defined as a scanty growth of bacteria. Every separate morphological colony species was calculated by a digital colony counter after incubation. All identical individual colonies were also handled for Gram staining, and pure cultures were obtained and also used for identification. All samples were operated along with the procedures of Clinical Microbiology Laboratory Standard Operating Procedures ${ }^{11}$.

\section{Antibiotic sensitivity tests}

Antimicrobial susceptibility testing was carried out using the Kirby-Bauer disk diffusion method on Muller-Hinton agar according to CLSI guidelines. Antimicrobial susceptibility has been determined using commercial antimicrobial discs (Oxoid, UK). We selected ten antibiotics for ocular infection with a wide range of mechanisms of action, including drugs that target the cell wall, DNA, and protein (Table 2). After incubation, the antimicrobial effectiveness was determined by measuring the diameter of the inhibition zones. The bacterial strains were classified as Sensitive (S), Intermediate (I), or Resistant (R) according to the diameter of the inhibition zone ${ }^{12}$.

\section{Ethical approval}

The ethical approval was obtained from the Medical Research and Ethics Committee at the Faculty of Medicine and Health Sciences at Sana'a University with Document No. 412 dated July 1, 2019. All data, including patient identification, have been kept confidential and informed consent has been obtained from the persons themselves.

\section{RESULTS}

Five hundred and twenty one swab results from conjunctiva were performed, of which 206 (39.5\%) were deemed positive for bacterial culture. The isolation rate by bacteria species ranged from $0.5 \%$ to $28.2 \%$ (Table 1). The most common bacteria isolated was Branhamella catarrahalis with $28.2 \%$ of the total isolates, followed by $S$. aureus at $27.7 \%$, while Haemophilus influenzae and Staphylococcus epidermidis counted only $9.2 \%$ of total isolates. Other bacteria as Pseudomonas aeruginosa, Escherichia coli, S. pneumoniae were counted $3.4 \%, 3.9 \%$ and $3.4 \%$ respectively. There was also a low rate of isolation for other Gram negative and Gram positive bacteria. All organisms isolated have been listed in Table 1. Table 2 shows the sensitivity patterns of major bacteria isolated from conjunctivitis patients to the various antibiotics commonly used for ophthalmic infections. In S. aureus isolates, ophthalmic antibiotic resistance varied from $10.5 \%$ for polymaxin B to $66.7 \%$ for erythromycin. In Branhamella catarrahalis isolates, ophthalmic antibiotic resistance ranged from $3.4 \%$ for levofloxacin to $69 \%$ for erythromycin. In Haemophilus influenzae isolates, ophthalmic antibiotic resistance varied from $0.0 \%$ for ciprofloxacin and polymaxian B to $42.1 \%$ for erythromycin and azithromycin. In Staphylococcus epidermidis isolates, the rate of resistance to the ophthalmic antibiotic ranged from $10.8 \%$ for ofloxacin, moxifloxacin, polymyxin $\mathrm{B}$, chloramphenicol and fusidic acid to $47.3 \%$ for erythromycin and azithromycin. 
Table 1: Pathogens isolated from 512 adult patients of various adult age groups (16 years to 52 years) with conjunctivitis.

\begin{tabular}{lcc}
\hline Pathogens & Number & Percentage \\
\hline S. aureus & 57 & 27.7 \\
Staphylococcus epidermidis & 19 & 9.2 \\
S. pneumoniae & 7 & 3.4 \\
Streptococcus viridians & 2 & 0.97 \\
Streptococcus pyogenes & 3 & 1.5 \\
Lancefield Group C streptococci & 1 & 0.5 \\
Streptococcus faecalis & 2 & 0.97 \\
Non-hemolytic streptococci & 1 & 0.5 \\
Branhamella catarrahalis & 58 & 28.2 \\
Haemophilus influenzae & 19 & 9.2 \\
Pseudomonas aeruginosa & 7 & 3.4 \\
Escherichia coli & 8 & 3.9 \\
Enterobacter species & 2 & 0.97 \\
Klebsiella species & 3 & 1.5 \\
Serratia marcescens & 3 & 1.5 \\
Proteus species & 3 & 1.5 \\
Moraxella species & 7 & 3.4 \\
Candida albicans & 4 & 1.9 \\
Total non-significant growth & 315 & 60.5 \\
Total positive growth & 206 & 39.5 \\
Total tested for eye swab culture & 521 & 100 \\
\hline
\end{tabular}

\section{DISCUSSION}

The positivity rate for bacterial culture eye swab in the current study was $39.5 \%$, this result is higher than that reported in adult patients presenting to their general practitioner with red eyes, purulent (mucous) or prickly secretions in the eyelids; It was found that approximately $32 \%$ of them have bacterial causes ${ }^{2}$. But this study bacterial rate was higher than the lowpositive isolation rate of Silvester et al., in UK 2016, in which the bacterial rate was $15.8 \%$ of total conjunctivitis cases. Also other papers have shown variable rates of positive isolates ${ }^{13,14}$. An explanation of this difference can be understood by including all bacteria isolated in some studies rather than just pathogenic bacteria. In addition, the isolation rate may be lower than the actual rate as bacterial swabs were taken from all patients with suspected conjunctivitis including those with viral conjunctivitis. Many patients attended after they had already started treatment with topical antibiotics, as this may have reduced the rate of positive isolation.

Table 2: The susceptibility patterns of the main bacterial isolated from conjunctivitis patients towards the different commonly used antibiotics for ocular infections.

\begin{tabular}{|c|c|c|c|c|c|c|c|c|}
\hline \multirow{3}{*}{ Antibiotics } & \multicolumn{8}{|c|}{ Resistant } \\
\hline & \multicolumn{2}{|c|}{ S. aureus, $\mathrm{n}=57$} & \multicolumn{2}{|c|}{$\begin{array}{c}\text { Branhamella } \\
\text { catarrahalis, } \mathrm{n}=58\end{array}$} & \multicolumn{2}{|c|}{$\begin{array}{c}\text { Haemophilus } \\
\text { influenza, } n=19\end{array}$} & \multicolumn{2}{|c|}{$\begin{array}{c}\text { Staphylococcus } \\
\text { epidermidis, } n=19\end{array}$} \\
\hline & No. & $\%$ & No. & $\%$ & No. & $\%$ & No & $\%$ \\
\hline Ciprofloxacin & 16 & 28 & 3 & 5.2 & 0 & 00 & 3 & 15.8 \\
\hline Ofloxacin & 13 & 22.8 & 4 & 6.8 & 1 & 5.2 & 2 & 10.8 \\
\hline Levofloxacin & 16 & 28 & 2 & 3.4 & 1 & 5.4 & 3 & 15.8 \\
\hline Moxifloxacin & 15 & 26.3 & 4 & 6.8 & 1 & 5.4 & 2 & 10.8 \\
\hline Tobramycin & 27 & 47.3 & 15 & 25.8 & 2 & 10.8 & 5 & 26.3 \\
\hline Gentamicin & 25 & 43.8 & 13 & 22.4 & 2 & 10.8 & 3 & 15.8 \\
\hline Erythromycin & 38 & 66.7 & 40 & 69 & 8 & 42.1 & 9 & 47.3 \\
\hline Azithromycin & 36 & 63.2 & 36 & 62 & 8 & 42.1 & 9 & 47.3 \\
\hline Bacitracin & 22 & 38.6 & 20 & 34.5 & 6 & 31.6 & 4 & 21 \\
\hline Polymyxin B & 6 & 10.5 & 3 & 5.2 & 00 & 00 & 2 & 10.8 \\
\hline Neomycin & 25 & 43.8 & 3 & 5.2 & 1 & 5.2 & 3 & 15.8 \\
\hline Chloramphenicol & 24 & 42.1 & 12 & 20.7 & 3 & 15.8 & 2 & 10.8 \\
\hline Fusidic Acid & 7 & 12.2 & 6 & 10.3 & 3 & 15.8 & 2 & 10.8 \\
\hline
\end{tabular}

In the current study, the most common bacteria isolated was Branhamella catarrahalis with $28.2 \%$ of the total isolates, followed by $S$. aureus at $27.7 \%$, while Haemophilus influenzae was less common. The results of the present study differ from those reported by Azari and Barney 2013; and Smith and Waycaster (2009) in the USA where the most common pathogens of bacterial conjunctivitis in adults were $S$. aureus, followed by $S$. pneumoniae and Haemophilus influenzae $e^{2,7}$. Similar to what has been reported in studies from the US and Britain, ${ }^{5,6,10} S$. aureus was the most common organism. The high infection rate of $S$. aureus is likely associated with cross-infection as reported by other workers. Table 2 shows the sensitivity patterns of major bacteria isolated from conjunctivitis patients to the various antibiotics commonly used for ophthalmic infections with high rates of resistance to ophthalmic antibiotics e.g $S$. 
aureus isolates, ophthalmic antibiotic resistance varied from $10.5 \%$ for polymyxin $\mathrm{B}$ to $66.7 \%$ for erythromycin. For this reason, there is clearly no single drug that treats these various types of bacteria. In the absence of laboratory facilities, some generalizations can be made as guidelines for treating conjunctivitis in adults, as fusidic acid and neomycin can be administered and they will be effective against most bacteria isolated in this age group, depending on the results of this study. Alternatively, moxifloxacin and polymyxin B may be used. Chloramphenicol can be used in all age groups after the neonatal period, as the dominant causative organisms isolated in these age groups, namely S. pneumoniae and/or Haemophilus influenzae, were sensitive to chloramphenicol. However, ophthalmic formulations of this drug are absorbed into the blood and are known to cause aplastic anemia ${ }^{15}$. Therefore, short-term use of chloramphenicol should be restricted to infections resistant to less serious agents. Pseudomonas-eye infections may require systemic and topical treatment with appropriate antimicrobials ${ }^{16}$. In non-ophthalmic infections, excessive and inappropriate use of antimicrobials increased resistance of organisms ${ }^{8}$. Hence, monitoring of antimicrobial susceptibility and trends of resistance is important for ophthalmic antibiotics and antibiotics in general.

\section{CONCLUSION}

The commonest causative organisms in the adult age groups were Branhamella catarrahalis and S. aureus. Obviously there is no single drug that will treat these varied species of bacteria; therefore bacteriological culture and in vitro sensitivity to ocular antibiotics should be sought as much as possible. Where laboratory facilities are not available, certain generalizations could be made as guidelines for conjunctivitis treatment. Antibiotics prescription should be delayed awaiting a bacterial etiology are confirmed, and educational brochures should be distributed to emergency and general care practitioners. The development of novel agents with broad-spectrum antimicrobial activity may provide potential new pathways without the defect of resistance.

\section{AUTHORS' CONTRIBUTION}

The manuscript was carried out, written, and approved in collaboration with all authors.

\section{ACKNOWLEDGEMENTS}

The clinical samples culturing, and microbiology diagnosis were done at National Center of Public Health laboratories Sana'a (NCPHL).

\section{CONFLICT OF INTEREST}

No conflict of interest associated with this work.

\section{REFERENCES}

1. American Academy of Ophthalmology Cornea/External Disease Preferred Practice Pattern Panel. Conjunctivitis Preferred Practice Pattern®. San Francisco, CA: American Academy of Ophthalmology; 2018.

2. Azari AA, Barney NP. Conjunctivitis: a systematic review of diagnosis and treatment. JAMA 2013; 310(16):1721-1729. https://doi.org/10.1001/jama.2013.280318

3. Shields T, Sloane PD. A comparison of eye problems in primary care and ophthalmology practices. Fam Med. 1991; 23(7):544-546. PMID: 1936738.

4. Davis H, Mant D, Scott C, Lasserson D, Rose PW. Relative impact of clinical evidence and over-the-counter prescribing on topical antibiotic use for acute infective conjunctivitis. $\mathrm{Br}$ J Gen Pract 2009; 59(569):897-900.

https://doi.org/10.3399/bjgp09X473132

5. Silvester A, Neal T, Czanner G, et al. Adult bacterial conjunctivitis: resistance patterns over 12 years in patients attending a large primary eye care centre in the UK. BMJ Open Ophth 1:e000006.

https://doi.org/10.1136/ bmjophth-2016-000006

6. Kaufman HE. Adenovirus advances: new diagnostic and therapeutic options. Curr Opin Ophthalmol 2011; 22(4):290293. https://doi.org/10.1097/ICU.0b013e3283477cb5

7. Smith AF, Waycaster C. Estimate of the direct and indirect annual cost of bacterial conjunctivitis in the United States. BMC Ophthalmol 2009; 9:13. https://doi.org/10.1186/1471-2415-9-13

8. Everitt HA, Little PS, Smith PW. A randomised controlled trial of management strategies for acute infective conjunctivitis in general practice. BMJ 2006; 333(7563):321. https://doi.org/10.1136/bmj.38891.551088.7C

9. Yamaguchi T. Inflammatory response in dry eye. Invest Ophthalmol Vis Sci. 2018; 59(14):DES192-DES199. https://doi.org/10.1167/iovs.17-23651

10. Udeh BL, Schneider JE, Ohsfeldt RL. Cost effectiveness of a point-of-care test for adenoviral conjunctivitis. Am J Med Sci 2008; 336(3):254-264. https://doi.org/10.1097/MAJ.0b013e3181637417

11. Cheesbrough M. District laboratory practice in tropical countries, culturing bacterial pathogens; 45-62. Cambridge: Cambridge University Press; 2006.

12. Wayne PA. Clinical and Laboratory Standards Institute (CLSI) performance standards for antimicrobial disk diffusion susceptibility tests $19^{\text {th }}$ ed, 2009 approved standard. CLSI document M100-S19: 29

13. Rietveld RP, van Weert HC, Ter Riet G, Bindels PJ. Diagnostic impact of signs and symptoms in acute infectious conjunctivitis: systematic literature search. BMJ 2003; 327(7418):789. https://doi.org/10.1136/bmj.327.7418.789

14. Sheikh A, Hurwitz B, van Schayck CP, McLean S, Nurmatov U. Antibiotics versus placebo for acute bacterial conjunctivitis. Cochrane Database Syst Rev 2012; 9: CD00 1211.https://doi.org/10.1002/14651858.CD001211.pub3

15. Ohnsman CM. Exclusion of students with conjunctivitis from school: policies of state departments of health. J Pediatr Ophthalmol Strabismus. 2007; 44(2):101-105. https://doi.org/10.3928/01913913-20070301-03

16. Rietveld RP, Ter Riet G, Bindels PJ, Sloos JH, van Weert HC. Predicting bacterial cause in infectious conjunctivitis: cohort study on informativeness of combinations of signs and symptoms. BMJ 2004; 329(7459):206-210.

https://doi.org/10.1136/bmj.38128.631319 